\title{
Interference with gene expression induces rapid apoptosis in p53-null T lymphoma cells
}

\author{
R Ofir ${ }^{1}$, L-C Zhang ${ }^{1}$ and JM Adams ${ }^{*, 1}$ \\ 1 The Walter and Eliza Hall Institute of Medical Research, Post Office, Royal \\ Melbourne Hospital, Victoria 3050 Australia \\ * Corresponding author: JM Adams. Tel: +61 39345 2555; Fax: +61 39347 \\ 0852 \\ E-mail: adams@wehi.edu.au
}

Received 27.7.99; accepted 30.9.99

Edited by B Osborne

\begin{abstract}
Two p53-null T lymphoma cell lines proved to be highly sensitive to inhibition of gene expression. With either actinomycin $\mathrm{D}$ or cycloheximide, apoptosis commenced within $2 \mathrm{~h}$, as indicated by loss of membrane integrity, degradation of certain proteins (including the phosphatase calcineurin) and DNA fragmentation. These effects were ablated by co-expression of Bcl-2 or co-incubation with the caspase inhibitor Z-VAD-fmk. These results suggest that the apoptotic machinery is in place in these cells but held in check by an unknown labile protein, which probably acts upstream of Bcl-2. Although cycloheximide can activate the JNK or p38 MAP kinases in some cells, neither was implicated here. However, disruption of phosphoinositide 3-kinase signaling may be involved, because the cells were also sensitive to wortmannin. The high sensitivity of the p53-null lymphoma cells to inhibitors of gene expression suggests that such inhibitors might prove useful in the cytotoxic therapy of certain tumors.
\end{abstract}

Keywords: apoptosis; cycloheximide; p53; cytotoxic therapy

\section{Introduction}

The relationship of new gene expression to programmed cell death is complex. The basic machinery for apoptosis, which relies upon activation of the special set of cysteine proteases termed caspases ${ }^{1}$ seems to be in place in almost all cell types. ${ }^{2}$ Less is understood, however, about the regulatory apparatus that controls this machinery. The Bcl-2 family of cytoplasmic proteins is known to have a major supervisory role, but how death signals impinge on this family, or override its influence, is less clear. ${ }^{3}$ The role of new gene expression in apoptosis differs dramatically in various cell types. In some cells, particularly thymocytes, the death elicited by certain cytotoxic stimuli, including treatment with glucocorticoids ${ }^{4}$ or activation of the T-cell receptor, ${ }^{5}$ can be largely blocked by inhibitors of RNA synthesis, such as actinomycin D, or of protein synthesis, such as cycloheximide. In marked contrast, such inhibitors actually augment or even trigger cell death in certain other cells, including several types of transformed cell lines. ${ }^{6-8}$ Hence, in certain cell types, maintenance of cell survival seems to require continual production of labile proteins that are as yet unidentified.

In cells with damaged DNA, the p53 tumor suppressor can be an important mediator of apoptosis. If $p 53$ is wildtype, DNA damage leads to stabilization and modification of the protein, and the resulting increase in the level and activity of this transcription factor alters the expression of critical target genes. ${ }^{9,10}$ How p53 induces apoptosis is not yet clear, but it can increase transcription of the bax gene, ${ }^{11}$ which encodes a pro-apoptotic member of the Bcl-2 family, as well as a number of other genes with less well understood roles. ${ }^{12}$

As the p53 gene is mutated, deleted or functionally compromised in a large proportion of tumors, it is important to learn how death is controlled in cells where p53 is not functional. The death of $T$ lymphoid cells has been widely studied. ${ }^{4,5}$ Although the apoptosis of thymocytes following DNA damage requires $\mathrm{p} 53,{ }^{13,14}$ that of activated $\mathrm{T}$ cells and $\mathrm{T}$ lymphoma cells does not. ${ }^{15}$ Similarly, p53 is not required for the cytotoxicity mediated by either glucocorticoids or activation through the T-cell receptor. ${ }^{5,14}$

Because transcription is required for the death of $T$ cells in response to several types of insult, we were surprised to find that p53-null $\mathrm{T}$ lymphoma cells were rapidly killed by inhibitors of gene expression. Their high sensitivity argues that these lymphoma cells are primed for apoptosis but protected by an unknown labile protein. The rapidity of the response suggested that this labile protein might impact on a signal transduction pathway. Therefore we have explored whether the death might involve activation of stressactivated kinases such as JNK or p38, which have often been implicated in apoptosis, ${ }^{16,17}$ or interruption of the phosphoinositide 3-kinase (PI3-kinase) pathway, which has critical roles in cell survival. ${ }^{18,19}$ Whatever the mechanism, the rapid cytotoxic response of certain tumor lines suggests that inhibitors of gene expression might well prove of value in the cytotoxic therapy of some malignancies.

\section{Results}

\section{High sensitivity of p53-null lymphoma cells to interference with gene expression}

In the course of studying apoptosis in the KO52DA20 T cell line, ${ }^{15}$ we noted that the cells were highly sensitive to interference with gene expression. Within $2 \mathrm{~h}$ of treatment of the cells in their normal culture medium with cycloheximide (10 $\mu \mathrm{g} / \mathrm{ml}$ ), a quarter had become permeable to trypan blue and exhibited the ladder of nucleosomal DNA fragments characteristic of apoptosis, and almost all were dead by $3 \mathrm{~h}$ (Figure 1, lanes 1-4). In marked contrast, treatment of a 
derivative line expressing $\mathrm{Bcl}-2$ resulted in no loss of membrane integrity or DNA fragmentation (Figure 1, lanes 5 and 6 ). The cytotoxicity probably reflects interference with gene expression, because actinomycin D (ActD) also provoked substantial DNA degradation within $3 \mathrm{~h}$ (Figure 1, lane 10). Equivalent results were seen with another p53-null lymphoma cell line (KO52FA2), of independent origin ${ }^{15}$ (data not shown). For comparison, treatment of the same lines with $\gamma$-irradiation or four cytotoxic drugs for $8 \mathrm{~h}$ killed only $10-35 \%$ of the cells. ${ }^{15}$ Thus, interference with the production of new RNA or protein is a particularly potent stimulus of apoptosis in these cells.

\section{Cycloheximide induces protein degradation inhibitable by $\mathrm{Bcl}-2$}

The rapidity of the response of the death machinery to cycloheximide treatment might implicate a labile protein kinase or phosphatase, particularly because cycloheximide is known to trigger some signal transduction pathways (see below). We therefore first explored whether cycloheximide altered the level of any phosphotyrosine proteins, which include many tyrosine kinases and their substrates, or that of the serine-threonine phosphatase calcineurin, which has been implicated in $\mathrm{Ca}^{2+}$-activated cell death ${ }^{20}$ and reported to associate with $\mathrm{Bcl}-2 .{ }^{21}$ Blots of protein samples from untreated cells and cells treated with cycloheximide for various times were probed with antibodies to phosphotyrosine or to calcineurin. In untreated cells, the phosphotyrosine antibody revealed a prominent polypeptide of approximately $60 \mathrm{kD}$ (Figure 2A, lane 1) and often also one of $93 \mathrm{kD}$ (see below). The $60 \mathrm{kD}$ polypeptide was rapidly affected by the cycloheximide treatment; after $2 \mathrm{~h}$, it was barely visible (Figure 2A, lanes 3-5). Similarly, the level of calcineurin had fallen markedly after treatment for $2 \mathrm{~h}$ (Figure 2B, lane 3 ).

These changes did not reflect general proteolysis (or unequal loading), because the level of the housekeeping gene product Hsp70 was unaffected. All the changes,

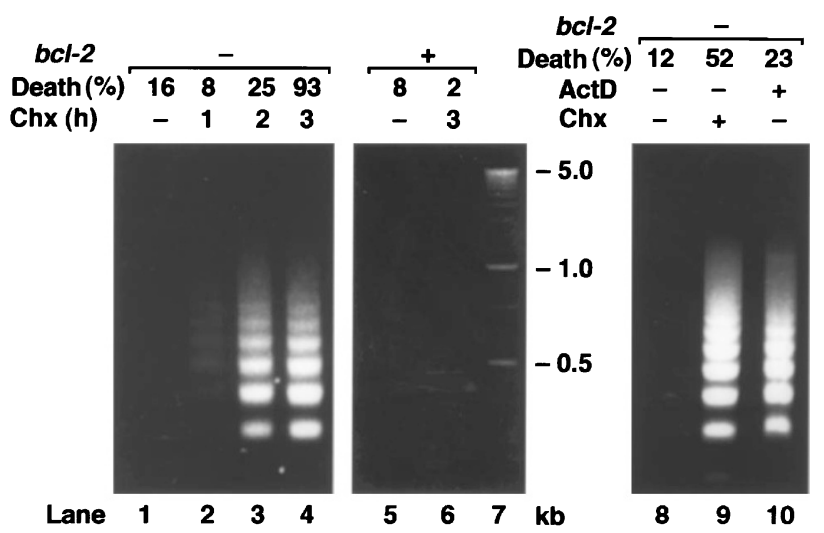

Figure 1 DNA fragmentation induced by cycloheximide and actinomycin $D$ is inhibitable by Bcl-2. KO52DA20 cells in lanes1 - 4 and 8-10, and KO52DA20/ bcl-2 in lanes 5-6, were treated with cycloheximide (Chx) or actinomycin D (ActD) as indicated. Cell viability was determined by trypan blue exclusion, and DNA released from nuclei was isolated for ladder analysis as described in Material and Methods. Lane 7 shows DNA size markers however, could be prevented by $\mathrm{Bcl}-2$. In the $\mathrm{Bcl}-2$ expressing lymphoma line KO52DA20/bcl-2, cycloheximide did not alter the level of the phosphotyrosine protein (Figure $2 \mathrm{~A}$, lanes 6 and 7) or that of calcineurin (Figure 2B, lanes $6-10)$. Hence, the losses of these proteins are likely to lie downstream of processes controlled by $\mathrm{Bcl}-2$, such as the activation of caspases.

\section{Z-VAD.fmk but not YVAD.cmk prevents both the protein changes and the apoptosis induced by cycloheximide}

To investigate whether the effects evoked by cycloheximide were mediated by caspases, we first tested whether they could be prevented by the inhibitor Z-VAD.fmk, which inactivates all the known caspases. Pretreatment of KO52DA20 cells for $4 \mathrm{~h}$ with Z-VAD.fmk $(50 \mu \mathrm{M})$ blocked cycloheximide-mediated apoptosis, as assessed by trypan blue exclusion and by internucleosomal cleavage of DNA (Figure 3A, lanes 1-3). Z-VAD.fmk also precluded the loss of the 60- and $93-\mathrm{kD}$ phosphotyrosine proteins (Figure $3 \mathrm{~B}$ ) and of calcineurin (Figure $3 \mathrm{C}$ ). Thus, all the changes observed probably reflect degradation by caspases. Because lymphocytes are killed very effectively by engagement of the receptor CD95 (Fas), we also tested the effect of YVAD.cmk, an effective inhibitor of caspases such as caspase-8, which is critical for apoptosis mediated by CD95. ${ }^{22,23}$ No protection was provided by YVAD.cmk (data not shown). Hence it is likely that cycloheximide-mediated apoptosis proceeds mainly via caspases other than caspase-8, such as caspase- 9 and caspase- 3 , which constitute the major pathway controlled by $\mathrm{Bcl}-2 .^{3}$

A

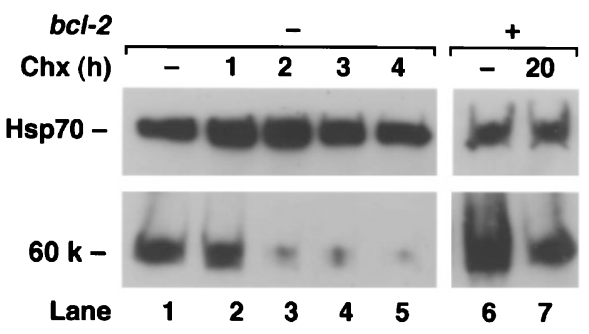

B

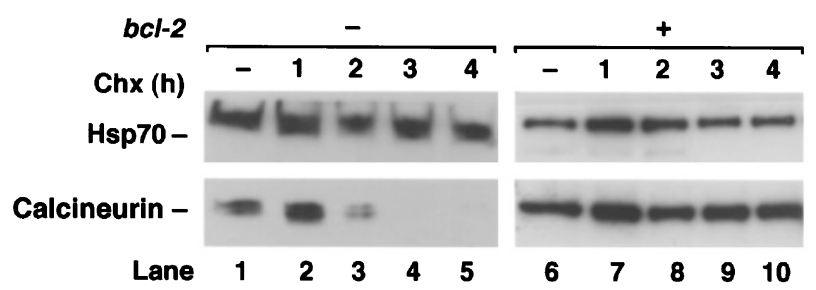

Figure 2 Loss of calcineurin and tyrosine-phosphorylated proteins induced by cycloheximide. KO52DA20 or KO52DA20/bcl-2 cells were treated with cycloheximide for the indicated periods, and lysates fractionated and blotted (see Materials and Methods). The filters were probed with antibodies to phophotyrosine (A) or to calcineurin (B). As a loading control, the blots were probed with monoclonal Hsp70 antibody 


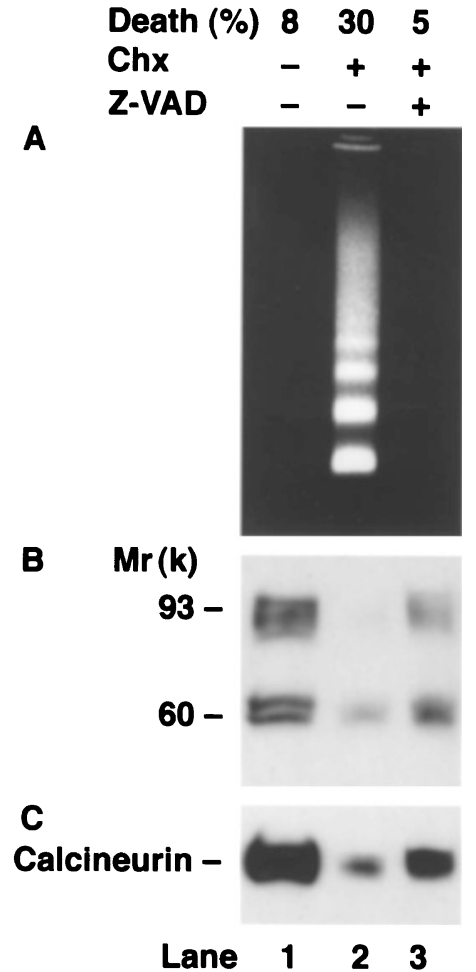

Figure 3 Caspase inhibitor blocks cycloheximide-induced DNA fragmentation and the degradation of calcineurin and tyrosine-phosphorylated proteins. K052DA20 cells were untreated (lane 1), treated with cycloheximide alone (lane 2) or in combination with Z-VAD.fmk, which was added $4 \mathrm{~h}$ previously (lane 3). (A) DNA fragmentation assay (as described for Figure 1). (B) Western blot with anti-phosphotyrosine antibody. (C) Western blot with anti-calcineurin antibody

\section{Activation of the JNK or p38 kinase pathways is not implicated}

Treatment of many cells with cycloheximide induces activation of two stress-associated kinase modules: one pathway includes Jun $\mathrm{N}$-terminal kinase (JNK), also known as stress-activated protein kinase (SAPK), which can then phosphorylate c-Jun, and the other activates the p38 kinase, which promotes jun transcription. ${ }^{16,17}$ In some but not all systems, sustained activation of the JNK pathway is thought to contribute to apoptosis. ${ }^{17}$ To assess whether these pathways were implicated in the death of the p53-null lymphoma cells, we first tested whether cycloheximide treatment led to c-Jun phosphorylation, by Western blot analysis with an antibody specific for phospho-Jun protein (Figure 4). Control fibroblasts irradiated with UV exhibited the expected 50-kD Jun polypeptide (Figure 4A, compare lanes 1 and 2). No such band appeared, however, on cycloheximide treatment of KO52DA20 cells (Figure 4A, lanes $3-5$ ), and a 50-kD band appeared in KO52FA2 cells only after treatment with cycloheximide for $2 \mathrm{~h}$, subsequent to the onset of apoptosis (Figure 4A, lanes 6-8). These results suggest that Jun phosphorylation is not required to trigger apoptosis in these cells.

We also tested directly for the presence of activated p38 and JNK, using antibodies specific for the activated forms,
A

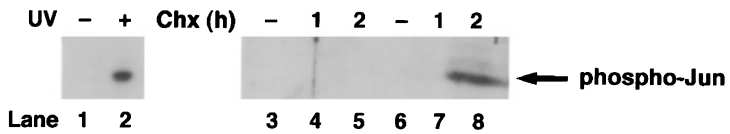

B

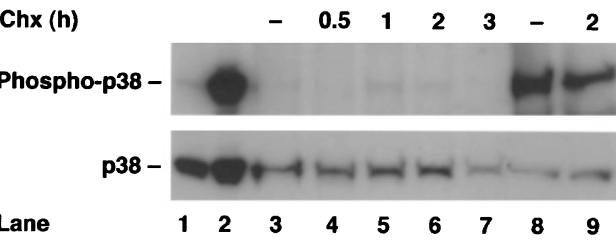

C

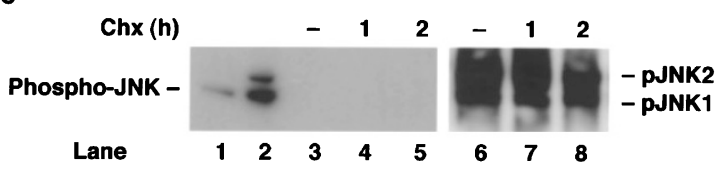

Figure 4 JNK and p38 kinases are not activated by treatment with cycloheximide. Cells were treated with $\mathrm{Chx}$ as indicated, and proteins detected by Western blotting with specific antibodies. (A) Detection of phospho c-Jun. Control NIH3T3 cells untreated or UV-treated (lanes 1 and 2, respectively); KO52DA20 cells (lanes $3-5$ ); KO52FA2 cells (lanes $6-8$ ). (B) Detection of phospho-p38 kinase. C-6 glioma cells untreated or treated with anisomycin (lanes 1 and 2, respectively); KO52DA20 cells (lanes 3-7); K052FA2 cells (lanes 8 and 9). (C) Detection of phospho-JNK. NIH3T3 cells untreated or UV-treated (lanes 1 and 2, respectively); KO52DA20 cells (lanes $3-5$ ); KO52FA2 cells (lanes $6-8$ )

which are phosphorylated on specific T-X-Y sites. ${ }^{17}$ Figure $4 \mathrm{~B}$ shows that UV-irradiated C-6 glioma cells yielded the expected band of phospho-p38 kinase (lane 2), but no such band appeared in cycloheximide-treated KO52DA20 cells (lanes 3-7). Although one did appear in KO52FA2 cells, it was present even before the treatment and no increase was evident (Figure 4B, lanes 8 and 9). Similarly, activated JNK (p46 pJNK1 and p54 pJNK2) could be readily detected in fibroblasts treated with UV (Figure 4C, lanes 1 and 2). These bands did not appear in cycloheximide-treated KO52DA20 cells (Figure 4C, lanes 3-5), and both were present in KO52FA2 cells at a comparable level before and after the treatment (lanes 6-8). The differences between the two cell lines presumably reflect different oncogenic changes during the evolution of the lines. In any case, these results suggest that neither the p38 kinase nor the JNK pathway is required to trigger apoptosis in these cells.

\section{Potential involvement of the PI3-kinase pathway}

PI3-kinase is strongly implicated in signal transduction pathways that control cell survival. ${ }^{18,19}$ To assess whether $\mathrm{PI}$-kinase signaling might be important in the T lymphoma cells, we treated the cells for $3 \mathrm{~h}$ with the specific PI3-kinase inhibitor wortmannin. Figure 5 shows that KO52DA20 but not KO52DA20/bcl-2 cells were killed by this inhibitor as effectively as by cycloheximide. Hence it is possible that cycloheximide induces apoptosis in these cells by blocking synthesis of a labile protein that influences the PI3-kinase pathway. Alternatively, the PI3-kinase pathway might induce 


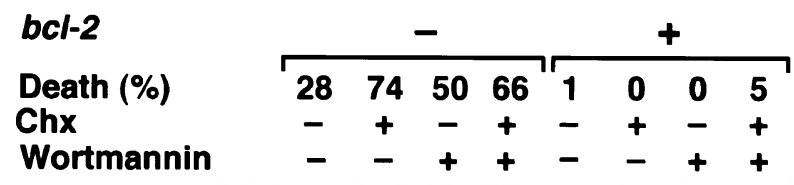

\section{$\begin{array}{lllllllllll}\text { Lane } & k b & 1 & 2 & 3 & 4 & 5 & 6 & 7 & 8 & 9\end{array}$}

Figure 5 Lymphoma cells are sensitive to the PI3-kinase-inhibitor wortmannin. KO52DA20 or K053DA20/bcl-2 cells were exposed to wortmannin $(5 \mu \mathrm{M})$ and/or cycloheximide $(10 \mu \mathrm{g} / \mathrm{ml})$ as indicated for $3 \mathrm{~h}$ in their normal growth medium and the samples analyzed as in Figure 1

expression of a labile protein needed for cell survival (see below).

\section{Discussion}

We have shown here that lymphoma cell lines derived from p53-null mice ${ }^{15}$ are remarkably sensitive to inhibition of gene expression. On treatment with either cycloheximide or actinomycin D, cells began to die within an hour and most were dead within a few hours. This response is unusually rapid, because substantial killing of the same cells by $\gamma$ irradiation or various potent cytotoxic drugs typically required $8-24$ h. ${ }^{15}$ Nevertheless, like the death induced by all those stimuli, the death induced by interference with new gene expression has the hallmarks of apoptosis and can be ablated by $\mathrm{Bcl}-2$ or by the broad spectrum caspase inhibitor ZVAD.fmk.

The cycloheximide-treated cells exhibited proteolysis of both phosphotyrosine proteins and the $\mathrm{Ca}^{2+} /$ calmodulindependent protein phosphatase calcineurin (Figure 2 and $3 B, C)$. Loss of these proteins is not likely to be involved in the initiation of the apoptotic process, because it did not clearly precede the appearance of DNA fragmentation. Indeed, their disappearance must instead follow caspase activation, because it was blocked by the caspase inhibitor Z-VAD.fmk, as well as by Bcl-2. Nevertheless, loss of these proteins could contribute to the execution stage of apoptosis. Although the identity of the 60- and 93-kD phosphotyrosine proteins (Figure $3 \mathrm{~B}$ ) is unknown, the former has a size similar to Src family tyrosine kinases.
The degradation of calcineurin could also be relevant to the ultimate demise of the cell, because calcineurin regulates intracellular $\mathrm{Ca}^{2+}$ signaling and signal transduction. ${ }^{24}$ Its catalytic domain has a potential caspase-3 cleavage site (DYVD ${ }^{121}$ ) similar to the consensus DEAD. ${ }^{25}$ Although a dozen protein kinases are known caspase targets, ${ }^{26}$ calcineurin is, to our knowledge, the first protein phophatase shown to be degraded during apoptosis, adding to the evidence that alterations in signal transduction contribute to programmed cell death.

The results presented here suggest that the apoptotic machinery is in place in these lymphoma cells but held in a latent form by a labile protein that promotes cell survival. Moreover, the pro-apoptotic effects of actinomycin D indicate that this protein is likely to be encoded by a short-lived mRNA. The ability of Bcl-2 to ablate the cycloheximide-induced changes suggests that the labile protein acts upstream of Bcl-2. Although there are as yet few clues to the nature of this protein, it might, for example, be a labile kinase or phosphatase that regulates the activity of members of the Bcl-2 family, because the activity of several family members is known to be influenced by phosphorylation. $^{3}$ When cycloheximide prevents new synthesis of the putative labile protein, the death machinery would then be activated, unless countermanded by the over-expression of Bcl-2.

In several cell types, protein synthesis inhibitors such as anisomycin or cycloheximide provoke sustained activation of the JNK/SAPK and p38 kinase pathways. ${ }^{16,17}$ With other types of stress, their activation is transient, apparently because the activity of the kinases is soon reduced by concomitantly induced dual-specificity phosphatases, such as MKP1. ${ }^{27,28}$ By preventing synthesis of these labile phosphatases, the protein synthesis inhibitors might sustain the kinase activity, and that can lead to apoptosis in certain systems. ${ }^{17}$ With the p53-null lymphoid lines, however, we found no convincing evidence implicating either the p38 or JNK pathway in the cycloheximide-induced death (Figure 4).

PI3-kinase appears to be necessary for the survival of the lymphoma cells, because they were rapidly killed by its specific inhibitor wortmannin, unless $\mathrm{Bcl}-2$ was also expressed (Figure 5). This kinase has a major role in the transmission of survival signals from cytokine receptors. ${ }^{18,19}$ The best understood pathway leads through the PI3-K, PDK and Akt kinases to phosphorylation of the death agonist $B A D,{ }^{29,30}$ which is then sequestered in the cytoplasm by 14-3-3 proteins and thereby prevented from inactivating pro-survival Bcl-2 family members. ${ }^{31}$ The labile protein needed for survival of the lymphoma cells could be a component (or positive regulator) of this pathway or of another pathway through PI-3 kinase. For instance, PI-3K has also very recently been implicated in activation of NF$\kappa \mathrm{B},{ }^{32}$ which can promote cell survival. However, it is also possible that wortmannin and cycloheximide affect different pathways.

Recently the 'death receptor' CD95 (Fas) was implicated in cycloheximide-induced death by evidence that a dominant-interfering mutant of FADD, which couples CD95 ligation to caspase-8 activation, ${ }^{22}$ diminished the 
killing of the human Jurkat T-cell line by cycloheximide. ${ }^{33}$ That result might reflect some unusual feature of that line, because we found that killing by cycloheximide was not blocked by the effective caspase-8 inhibitor YVAD.cmk, whereas the more general caspase inhibitor Z-VAD was highly protective, as was Bcl-2. Bcl-2 does not block CD95induced death in lymphocytes, ${ }^{34}$ and a dominant-negative FADD transgene that blocked CD95-induced death did not impede any cytotoxic response that could be blocked by $\mathrm{Bcl}-2 .^{35}$

A number of the oncogenic changes in an emerging neoplastic clone, such as Myc overexpression, render the cells more susceptible to apoptosis. ${ }^{36,37}$ It may be relevant that the two lymphomas studied here lack p53, as did several of those shown previously to be very sensitive to cycloheximide. Although wild-type p53 can induce apoptosis in thymocytes in response to DNA damage but not other stresses, ${ }^{13-15}$ it seems possible that, in the absence of p53, certain cells are either inherently more susceptible to apoptosis or develop adaptations or mutations that render them so. That might explain why a recent review found that very few types of tumors exhibit a clear correlation between the presence of wild-type p53 and susceptibility to apoptosis. $^{38}$ Indeed, some p53-null cells have proven to be more sensitive to certain chemotherapeutic drugs. ${ }^{39-41}$ Hence, the role of p53 in apoptosis may be influenced by cellular background and oncogenic changes, as well as the nature of the stress.

The very rapid death induced by inhibitors of gene expression in the lymphomas studied here and in certain other tumor cell lines ${ }^{6-8}$ suggests that, for a subset of tumors, drugs that inhibit gene expression for a short time might well have potential in cytotoxic therapy. Any such inhibitor having a suitable therapeutic index might prove efficacious either on its own or as an adjunct to conventional therapy. Simple in vitro tests for apoptosis on various tumor samples might allow a rapid screen for the individual tumors most likely to be susceptible to such inhibitors. Inhibitors of the PI3K pathway may also prove to have therapeutic potential.

\section{Material and Methods}

\section{Cell lines, reagents and antibodies}

The cell lines K052DA20 and KO52FA2 used in this study originated from thymic $T$ lymphomas that arose in different $\mathrm{p} 53^{-1-}$ mice; both these lines and a derivative of the former carrying an introduced $b c l-2$ gene (KO52DA20/bcl-2) were described previously. ${ }^{15}$ The caspase inhibitors benzyloxycarbonyl-Val-Ala-DL-Asp-fluoromethylketone (ZVAD.fmk) and Phe-Val-Ala-Asp-chloromethylketone (YVAD.cmk) were purchased from Bachem (Bubendorf, Switzerland). Cycloheximide and actinomycin D came from Sigma.

The monoclonal antibodies used were anti-calcineurin (G1821847, PharMingen), anti-phosphotyrosine (4G10, Upstate Biotechnology, NY, USA), anti-phospho-JNK (Santa Cruz Biotechnology) and anti Hsp70 (provided to Dr. R Anderson by W Welsh, San Francisco, USA). Rabbit polyclonal antibodies included anti-phospho c-Jun (Ser63), anti-phospho-p38 kinase (IgG) and anti-p38 MAP kinase
(IgG) (New England Biolabs). The horseradish peroxidase-conjugated anti-mouse and anti-rabbit immunoglobulin secondary antibodies were from Silenus (Melbourne, Australia).

\section{Cellular viability assay and DNA-ladder analysis}

Apoptosis was induced by incubation of the lymphoma cell lines for the times indicated in Results with cycloheximide $(10 \mu \mathrm{g} / \mathrm{ml})$, actinomycin $\mathrm{D}(1 \mu \mathrm{g} / \mathrm{ml})$ or wortmannin $(5 \mu \mathrm{M})$ in their normal serum-supplemented growth medium. ${ }^{15}$ In experiments with caspase inhibitors, cells were preincubated for $4 \mathrm{~h}$ with Z-VAD.fmk $(50 \mu \mathrm{M})$ or YVAD.cmk $(100 \mu \mathrm{M})$. Cultured lymphoma cells were adjusted to the same density before treatment and viable and non-viable cells enumerated by trypan-blue dye exclusion. For electrophoretic analysis of the apoptotic DNA 'ladder', ${ }^{42}$ cells (at $1.0 \times 10^{6} / \mathrm{ml}$ ) were washed in cold PBS once and the pellet was resuspended gently in $0.5 \mathrm{ml}$ of lysis buffer $(10 \mathrm{mM}$ Tris$\mathrm{HCl}, \mathrm{pH} 7.4,1 \mathrm{mM}$ EDTA (TE) and $0.2 \%$ Triton X-100), incubated for $30 \mathrm{~min}$ at room temperature and then centrifuged in a microfuge (12000 r.p.m. for $30 \mathrm{~min}$ ). DNA was precipitated from the supernatant (by addition of $150 \mu \mathrm{l} 5 \mathrm{M} \mathrm{NaCl}$ and $500 \mu$ l of ethanol for $1 \mathrm{~h}$ at $-70^{\circ} \mathrm{C}$ or overnight in $-20^{\circ} \mathrm{C}$ ) and recovered in a microfuge (12000 r.p.m. for $30 \mathrm{~min}$ ). The DNA pellet was resuspended in TE and treated with RNase for $1 \mathrm{~h}$ at $37^{\circ} \mathrm{C}$. The DNA samples (from equivalent numbers of cells) were electrophoresed in a $1 \%$ agarose gel and visualized by ethidium bromide staining.

\section{Immunoblotting}

After drug treatment, cells were washed in cold PBS once and lysed in cold lysis buffer with protease and phosphatase inhibitors: $50 \mathrm{mM}$ Tris$\mathrm{HCl}, \mathrm{pH} 7.4,1 \%$ Triton X-100, $150 \mathrm{mM} \mathrm{NaCl}, 0.25 \%$ sodium deoxycholate, $1 \mathrm{mM}$ EDTA, $1 \mathrm{mM} \mathrm{Na}_{3} \mathrm{VO}_{4}, 1 \mathrm{mM} \mathrm{NaF}$ and protease inhibitors (one tablet of 'complete' protein inhibitors (Boehringer Mannheim) per $50 \mathrm{ml}$ lysis buffer). Protein (20 $\mu \mathrm{g}$ per lane) was loaded on to 8 or $12 \%$ SDS polyacrylamide gels (precast gels from NOVEX, San Diego, CA, USA). Following electrophoresis, proteins were transferred to PVDF membranes (Immobilon-P from Millipore, Bedford, MA, USA). Non-specific binding sites were blocked by incubation for $>1 \mathrm{~h}$ in phosphate-buffered saline containing $0.1 \%$ Tween-20 and $10 \%$ skimmed milk or $5 \%$ bovine serum albumin (Sigma) for the anticalcineurin and anti-phosphotyrosine antibodies, respectively, and as indicated by the manufacturer for the others. Membranes were then incubated at room temperature for $2 \mathrm{~h}$ with primary antibody $(1 \mu \mathrm{g} / \mathrm{ml})$, followed by $1 \mathrm{~h}$ with the secondary antibody. Bands were visualized by enhanced chemiluminescence (Amersham, UK).

\section{Acknowledgements}

We are grateful to Dr. Andreas Strasser for the cell lines used here and for discussions. This work was supported by the National Heath and Medical Research Council (Reg. Key 973002) and by the US National Cancer Institute (CA43540 and CA80188). RO was supported by a fellowship from the International Union Against Cancer.

\section{References}

1. Thornberry NA and Lazebnik Y (1998) Caspases: enemies within. Science 281: $1312-1316$

2. Weil M, Jacobson MD, Coles HSR, Davies TJ, Gardner RL, Raff KD and Raff MC (1996) Constitutive expression of the machinery for programmed cell death. J. Cell Biol. 133: 1053-1059 
3. Adams JM and Cory S (1998) The Bcl-2 protein family: arbiters of cell survival. Science 281: $1322-1326$

4. Cohen JJ (1992) Glucocorticoid-induced apoptosis in the thymus. Semin. Immunol. 4: 363-369

5. Osborne BA, Smith SW, Liu ZG, McLaughlin KA, Grimm L and Schwartz LM (1994) Identification of genes induced during apoptosis in T lymphocytes. Immunol. Rev. 142: 301-320

6. Martin SJ, Lennon SV, Bonham AM and Cotter TG (1990) Induction of apoptosis (programmed cell death) in human leukemic HL-60 cells by inhibition of RNA or protein synthesis. J. Immunol. 145: $1859-1867$

7. Kochi SK and Collier RJ (1993) DNA fragmentation and cytolysis in U937 cells treated with diphtheria toxin or other inhibitors of protein synthesis. Exp. Cell Res. 208: 296-302

8. Vaux DL and Weissman IL (1993) Neither macromolecular synthesis nor myc is required for cell death via the mechanism that can be controlled by $\mathrm{Bcl}-2$. Mol. Cell. Biol. 13: $7000-7005$

9. Levine AJ (1997) p53, the cellular gatekeeper for growth and division. Cell 88: $323-331$

10. Mowat MR (1998) p53 in tumor progression: life, death, and everything. Adv. Cancer Res. 74: 25-48

11. Miyashita T and Reed JC (1995) Tumor suppressor p53 is a direct transcriptional activator of the human bax gene. Cell 80: 293-299

12. Polyak K, Xia Y, Zweier JL, Kinzler KW and Vogelstein B (1997) A model for p53induced apoptosis. Nature 389: 300-305

13. Lowe SW, Schmitt EM, Smith SW, Osborne BA and Jacks T (1993) p53 is required for radiation-induced apoptosis in mouse thymocytes. Nature 362 847-849

14. Clarke AR, Purdie CA, Harrison DJ, Morris RG, Bird CC, Hooper ML and Wyllie AH (1993) Thymocyte apoptosis induced by p53-dependent and independent pathways. Nature 362: 849-852

15. Strasser A, Harris AW, Jacks T and Cory S (1994) DNA damage can induce apoptosis in proliferating lymphoid cells via p53-independent mechanisms inhibitable by Bcl-2. Cell 79: 329-339

16. Minden A and Karin M (1997) Regulation and function of the JNK subgroup of MAP kinases. Biochim. Biophys. Acta 1333: F85-F104

17. Ip YT and Davis RJ (1998) Signal transduction by the c-Jun N-terminal kinase (JNK) - from inflammation to development. Curr. Opin. Cell Biol. 10: 205-219

18. Franke TF, Kaplan DR and Cantley LC (1997) PI3K: downstream AKTion blocks apoptosis. Cell 88: $435-437$

19. Franke TF and Cantley LC (1997) A bad kinase makes good. Nature 390: $116-$ 117

20. Shibasaki $\mathrm{F}$ and McKeon $\mathrm{F}$ (1995) Calcineurin functions in $\mathrm{Ca}^{2+}$-activated cell death in mammalian cells. J. Cell Biol. 131: 735-743

21. Shibasaki F, Kondo E, Akagi T and McKeon F (1997) Suppression of signalling through transcription factor NF-AT by interactions between calcineurin and $\mathrm{Bcl}$ 2. Nature 386: $728-731$

22. Ashkenazi A and Dixit VM (1998) Death receptors: signaling and modulation. Science 281: 1305-1308

23. Varfolomeev EE, Schuchmann M, Luria V, Chiannilkulchai N, Beckmann JS, Mett IL, Rebrikov D, Brodianski VM, Kemper OC, Kollet O, Lapidot T, Soffer D, Sobe T, Avraham KB, Goncharov T, Holtmann H, Lonai P and Wallach D (1998) Targeted disruption of the mouse Caspase 8 gene ablates cell death induction by the TNF receptors, Fas/Apo1, and DR3 and is lethal prenatally. Immunity 9:267 276
24. Guerini D (1997) Calcineurin: not just a simple protein phosphatase. Biochem Biophys. Res. Commun. 235: 271-275

25. Thornberry NA, Rano TA, Peterson EP, Rasper DM, Timkey T, Garcia-Calvo M, Houtzager VM, Nordstrom PA, Roy S, Vaillancourt JP, Chapman KT and Nicholson DW (1997) A combinatorial approach defines specificities of members of the caspase family and granzyme B. J. Biol. Chem. 272: 17907-17911

26. Bokoch GM (1998) Caspase-mediated activation of PAK2 during apoptosis: proteolytic kinase activation as a general mechanism of apoptotic signal transduction? Cell Death Differ. 5: 637-645

27. Guo YL, Kang B and Williamson JR (1998) Inhibition of the expression of mitogen-activated protein phosphatase-1 potentiates apoptosis induced by tumor necrosis factor- $\alpha$ in rat mesangial cells. J. Biol. Chem. 273: 10362-10366

28. Franklin CC, Srikanth S and Kraft AS (1998) Conditional expression of mitogenactivated protein kinase phosphatase-1, MKP-1, is cytoprotective against UVinduced apoptosis. Proc. Natl. Acad. Sci. USA 95: 3014-3019

29. del Peso L, González-Garcia M, Page C, Herrera R and Nuñez G (1997) Interleukin-3-induced phosphorylation of BAD through the protein kinase Akt. Science 278: $687-689$

30. Datta SR, Dudek H, Tao X, Masters S, Fu H, Gotoh Y and Greenberg ME (1997) Akt phosphorylation of BAD couples survival signals to the cell-intrinsic death machinery. Cell 91: 231-241

31. Zha J, Harada H, Yang E, Jockel J and Korsmeyer SJ (1996) Serine phosphorylation of death agonist BAD in response to survival factor results in binding to 14-3-3 Not BCL-X $X_{L}$. Cell 87: 619-628

32. Sizemore N, Leung S and Stark GR (1999) Activation of phosphatidylinositol 3kinase in response to interleukin-1 leads to phosphorylation and activation of the NF- $\kappa$ B p65/RelA subunit. Mol. Cell. Biol. 19: 4798-4805

33. Tang D, Lahti JM, Grenet J and Kidd VJ (1999) Cycloheximide-induced T-cell death is mediated by a fas-associated death domain-dependent mechanism. J. Biol. Chem. 274: 7245-7252

34. Strasser A, Harris AW, Huang DCS, Krammer PH and Cory S (1995) Bcl-2 and Fas/APO-1 regulate distinct pathways to lymphocyte apoptosis. EMBO J. 14 $6136-6147$

35. Newton K, Harris AW, Bath ML, Smith KGC and Strasser A (1998) A dominant interfering mutant of FADD/Mort1 enhances deletion of autoreactive thymocytes and inhibits proliferation of mature T lymphocytes. EMBO J. 17: 706-718

36. Evan $G$ and Littlewood T (1998) A matter of life and cell death. Science 281 $1317-1321$

37. Cory S, Vaux DL, Strasser A, Harris AW and Adams JM(1999) Insights from Bcl-2 and Myc: Malignancy involves abrogation of apoptosis as well as sustained proliferation. Cancer Res. 59: 1685s-1692s

38. Weller M (1998) Predicting response to cancer chemotherapy: the role of p53. Cell. Tissue Res. 292: $435-445$

39. Petty RD, Cree IA, Sutherland LA, HunterEM, Lane DP, Preece PE and Andreotti PE (1994) Expression of the p53 tumour suppressor gene product is a determinant of chemosensitivity. Biochem. Biophys. Res. Commun. 199: 264 270

40. Hawkins DS, Demers GW and Galloway DA (1996) Inactivation of p53 enhances sensitivity to multiple chemotherapeutic agents. Cancer Res. 56: 892-898

41. Wang Y, Blandino G, Oren M and Givol D (1998) Induced p53 expression in lung cancer cell line promotes cell senescence and differentially modifies the cytotoxicity of anti-cancer drugs. Oncogene 17: 1923-1930

42. Sellins KS and Cohen JJ (1987) Gene induction by $\gamma$-irradiation leads to DNA fragmentation in lymphocytes. J. Immunol. 139: 3199-3206 